\section{Géneros}

Multidisciplinary Journal of Gendet: Studies
Hipatia Press

www.hipatiapress.com

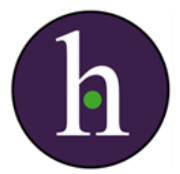

Instructions for authors, subscriptions and further details:

http://generos.hipatiapress.com

\title{
Redefining Rape: Sexual Violence in the Era of Suffrage and Segregation
}

Tinka Tabea Schubert $^{1}$

1) University of Barcelona. Spain

Date of publication: June $25^{\text {th }}, 2014$

Edition period: June 2014 - October 2014

To cite this article: Schubert, T. (2014). Redefining Rape: Sexual Violence in the Era of Suffrage and Segregation [Review of the book].

Multidisciplinary Journal of Gender Studies, 3(2), 457-459. doi:

10.4471/generos.2014.41

To link this article: http://dx.doi.org/10.447/generos.2014.41

\section{PLEASE SCROLL DOWN FOR ARTICLE}

The terms and conditions of use are related to the Open Journal System and to Creative Commons Attribution License (CC-BY). 

GÉNEROS-Multidisciplinary Journal of Gender Studies Vol. 3 No. 2 June 2014 pp. 457-459

\section{Review}

Freedman, E. (2013) Redefining Rape: Sexual Violence in the Era of Suffrage and Segregation. Cambridge, MA: Harvard University Press.

I

$\mathrm{n}$ historical moments of reviewing the legal definition of rape as we are recently experiencing with the complaints filed against 55 U.S. universities for not complying with Title IX guaranteeing the protection of their students from discrimination and sexual assaults on the grounds of gender, Estelle Freedman makes a historical review of the legal redefinitions of rape and the processes leading to these redefinitions. Her thesis is that rape is a term that varies across countries and over time which is shaped by the contestations of different social movements.

Starting with the origins of the term rape, the author draws from the Latin raptus for the definition of rape as violent theft which in the fifteenth century in the British Law was defined as the theft of a woman's virtue. The definition adopted by the American statutes based on the British Law refers to "the carnal knowledge of a woman when achieved by force and against her will by a man other than her husband" (p.4). Freedman depicts the changes in the social perception of rape highlighting the diverse social movements that have emerged and represent the main agents claiming for an increasingly narrowing of the definition. In her work, the author dares to emphasize not only the changing legal definition of rape but its implications for society and especially for the worth of women and the privilege of white men. Freedman underscores the relevance of the definition of rape on the status of citizenship. She further addresses the resistances of the privileged to introduce changes in the justice system that would lower their social 
position. In that sense, the first definitions only regard white unmarried women as possible victims of rape, with African American men as the rapist, and with signs of physical violence, excluding rapes against slaves and servants as well as those perpetrated by white men and husbands against their wives. Three major social justice movements had a cardinal impact on the redefinition of rape. These are: the women's rights movement, the antilynching movement and the anti-child-abuse movement. The women's movement brought the rapes perpetrated by white men forward. Consequently, the concept of criminal seduction was introduced and had much lower punishment than rape. Commonly, white men were held responsible for criminal seduction, whereas African American men were condemned for rape. At these times, rape was seen as a black crime, and a threat to white women. The anti-lynching movement were the first ones to claim for the same rights of African American women who were raped by white men. The media at that time played a crucial role in bringing this issue forward, as rapes of African American girls by white men were reported with greater visibility and focusing on white men as the perpetrators, contrary to the previous conception. The anti-child-abuse movement shed light on the abuse not only of girls but also of boys and put the focus even more on the white males as the perpetrators as well as on incest cases. Yet, the legal definition of that moment only contemplated heterosexual intercourse as rape. Thus, resistances focused attention on the perceived threat of homosexuals and especially on immigrants who were most commonly accused and convicted for these crimes.

Freedman's work is of great value to understanding the current debate on the definition of rape and the importance of consent, especially held in the context of rapes among college students as she analyzes all essential elements that intertwine in the definition of sexual violence. Her focus on the social justice movement together with the pressure by the public opinion in the media identifies these agents as a major contributor to the changing definition. But also the description of the resistances of those enjoying White Privilege (McIntosh, 1989), and especially white men, shed light to the possible struggles taking place in current times. Freedman makes it clear that the definition of rape is far more than terminology, but a social struggle that will only come to an end when inequalities are overcome. 
GÉNEROS -Multidisciplinary Journal of Gender Studies, 3(2) 459

\section{References}

McIntosh, P. (1989) White Privilege: Unpacking the Invisible Knapsack. Peace and Freedom, July/August:10-12.

Tinka Schubert, University of Barcelona tschubert@ub.edu 